\title{
Zvířecí kosti a kostry z raně středověkého sídliště v Brně-Medlánkách
}

\author{
Animal bones and skeletons from the early medieval \\ settlement in Brno-Medlánky \\ - Gabriela Dreslerová* -
}

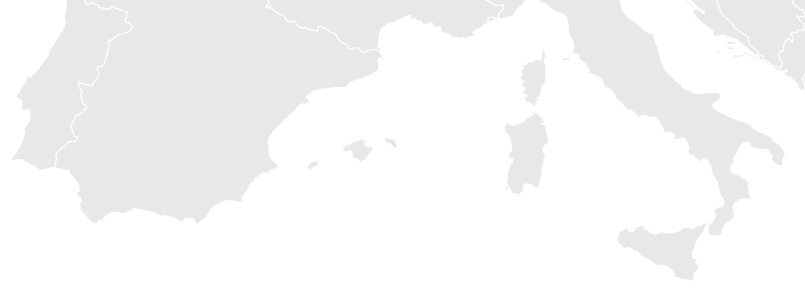

\begin{abstract}
KEYWORDS:
Archaeozoology - Early Middle Ages ( $8^{\text {th }}-9^{\text {th }}$ century) -

Rural settlement - Animal burials
\end{abstract}

\section{ABSTRACT}

The subject of the presented article is the processing of archaeozoological finds from the Early Middle Age settlement in Brno-Medlánky. This relatively small set consists of two different groups of osteological material. The first represents fragments of bones and teeth coming from the so-called kitchen waste. This set was processed by standard methods consisting in determining the anatomical affiliation, species, age, or sex, and the evidence of traces of manipulation (cutting, chopping, biting). The second group of finds representing several complete skeletons of animals is quite significant, as some of the animals were not consumed. Within the three features, 3 canine ( $2 \times a d o g$, $1 \times$ a wolf?), a horse and a pig skeleton in the secondary position were captured. Even in these cases, the basic characteristics of the animals were recorded, including age, sex, height, and post-mortem manipulation. The presence of preserved animal bodies from the settlement in Medlánky was compared with other documented finds of skeletons of animals from this period.
* Corresponding author - E-mail address: gabriela.dreslerova@muzeumbv.cz

https://doi.org/10.47382/pv0612-03

Copyright ( 2020 Czech Acad Sci, Inst Archaeology Brno, and the authors.

Competing interests: The authors have declared that no competing interests exist.

\section{Úvod}

Výzkum lokality Brno-Medlánky pod vedením M. Geislera (Archeologický ústav ČSAV, Ústav archeologické památkové péče Brno) proběhl ve dvou etapách v letech 1984 a 2007. V trati „Zadní žleby“ zachytil polykulturní osídlení, které zčásti představovalo slovanské sídliště starší a střední doby hradištní v časovém rozpětí 6./7. - 9. století (Benech 2019; Geisler 1987; 2008; Zapletalová 2001). V materiálovém projevu se lokalita sice neprofiluje jako regionálně významná, ale několik nálezů se vymyká z běžného průměru (Benech 2019, 145).

Část nálezového souboru tvořily i zvírecí kosti v počtu 1002 fragmentů, o celkové hmotnosti 21010 gramů. Pocházely z 37 objektů starší a střední doby hradištní. Z tohoto množství bylo druhově a anatomicky blíže určeno 789 (79 \%) fragmentů (Schmidt 1972; tab. 1.) Tento nadstandardně vysoký podíl určených kostí způsobilo dochování několika zvírecích skeletů (2x pes, 1x pes/vlk, 1x kůň, 1x prase domácí). Deponovaným kostrám náleží 572 fragmentů. Pozůstatky živočišné stravy reprezentuje něco málo přes 200 determinovaných nálezů. Zjednodušeně řečeno, na lokalitě se dochovalo více kostí z deponovaných jedinců než kostí ze zvířat zkonzumovaných.

V kategorii domácích zvířat je na lokalitě zastoupeno minimálně šest druhů. Relativní podíly kostí významných hospodářských druhů vypovídají o početní převaze tura domácího (obr. 1). V tomto hodnocení byly sledovány pouze fragmenty pocházející z kuchyňského odpadu. Z pohledu hmotnosti kostí se výsledek mění adekvátně k velikosti jednotlivých druhů a výrazně dominuje tur. Nutno ovšem podotknout, že toto rámcové schéma zaujímá širší časové období a rovněž ani výpovědní hodnota, vzhledem k objemu zpracovaných dat, není př́lišs statisticky významná.

Skupinu domestikovaných zvírrat doplňují v „kuchyňském odpadu“ ještě kosti slepice a $\mathrm{z}$ deponovaných koster kůň a pes.

Přibližně dvouprocentního podílu v souboru dosáhly kosti lovné fauny (pratur, jelen, srnec, prase divoké). Nejpočetněji je zde zastoupen jelen díky fragmentům parohu ( 9 kusů), což nemusí nutně vypovídat o lovecké aktivitě. Přichází v úvahu rovněž i sběr shozeného paroží, který je však identifikovatelný pouze podle př́tomné růžice parohu. K bližší druhové identifikaci skeletu psovité šelmy v objektu 578 viz níže.

Určení věkové struktury zvírat ze sídliště v Medlánkách je vzhledem k malému objemu souboru možné jen rámcově. Nálezy tura odpovídají svým vývojem a velikostí již skoro dospělým nebo zcela dospělým jedincům. Pouze u dvou nálezů se jedná prokazatelně o pozůstatky zvírat mladších 20 měsíců (Habermehl 1975). U prasete byly tyto nálezy o něco četnější, nebot̉ věk jeho porážky je vzhledem k výhradně masné produkci nižší. Ze zvíruat mladších jednoho roku pochází pět nálezů a dva fragmenty náleží jedincům mladším 20 měsíců. 
Na kostech se objevovaly standardní tafonomické znaky (tab. 2). Převažovaly zejména stopy po okousání šelmou. Doklady lidské manipulace spolu se stopami použití nástroje (řezání, sekání) byly zachyceny v šesti př́padech. Ve shodném počtu se vyskytly i známky ohoření, a to výlučně jen na fragmentech jeleního parohu, které byly převážně spáleny do černého zbarvení. Předloženo bylo i několik kostěných hrotitých nástrojů. Všechny bez výjimky byly vyrobeny z kosti holenní ovce/kozy a psa.

Zvířecí kosti z Medlánek se svým rozsahem řadí spíše k menším a statisticky méně významným souborům. Stojí za pozornost konstatovat, jak malý objem kostí z kuchyňského odpadu (430 nálezů) za dlouhou dobu existence osady (staro- až středohradištní období) z 37 objektů pochází.

\section{Doba hradištní}

\begin{tabular}{|c|c|c|}
\hline Druh & počet & $\begin{array}{l}\text { hmotnost } \\
\text { v gramech }\end{array}$ \\
\hline Bos primigenius f. taurus & 60 & 3899 \\
\hline Ovis ammon $\mathrm{f}$. aries & 2 & 12 \\
\hline Ovis/Capra & 21 & 178 \\
\hline Sus scrofa f. domestica & 133 & 1193 \\
\hline Equus caballus & 178 & 12680 \\
\hline Canis lupus $\mathrm{f}$. familiaris & 172 & 1315 \\
\hline Gallus gallus f. domestica & 9 & 13 \\
\hline Domácí & 575 & 19290 \\
\hline Bos primigenius & 1 & 18 \\
\hline Cervus elaphus & 10 & 52 \\
\hline Capreolus capreolus & 1 & 7 \\
\hline Sus scrofa & 1 & 39 \\
\hline Mollusca & 51 & 62 \\
\hline Volně žijící & 64 & 178 \\
\hline Canis lupus/f. familiaris & 137 & 334 \\
\hline Microtus sp. & 1 & 1 \\
\hline Domácí/volně žijící & 138 & 335 \\
\hline Homo sapiens sapiens & 12 & 49 \\
\hline Homo sapiens sapiens & 12 & 49 \\
\hline Určeno & 789 & 19852 \\
\hline $\mathrm{MV} / \mathrm{SV}$ & 1 & 2 \\
\hline SV & 151 & 301 \\
\hline VV & 61 & 855 \\
\hline Neurčeno & 213 & 1158 \\
\hline Celkem & 1002 & 21010 \\
\hline
\end{tabular}

Tab. 1. Zastoupené zviŕrecí druhy podle počtu a hmotnosti fragmentů, použité zkratky: MV/SV malá až střední velikost zvířete (pes...), SV - střední velikost zvířete (prase...), VV - velká velikost zvířete (tur...).

Tab. 1. Representation of animal species according to the number and weight of fragments, abbreviations used: MV/SV small to medium animal size (dog...), SV - medium animal size (pig...), VV - large animal size (cattle...).

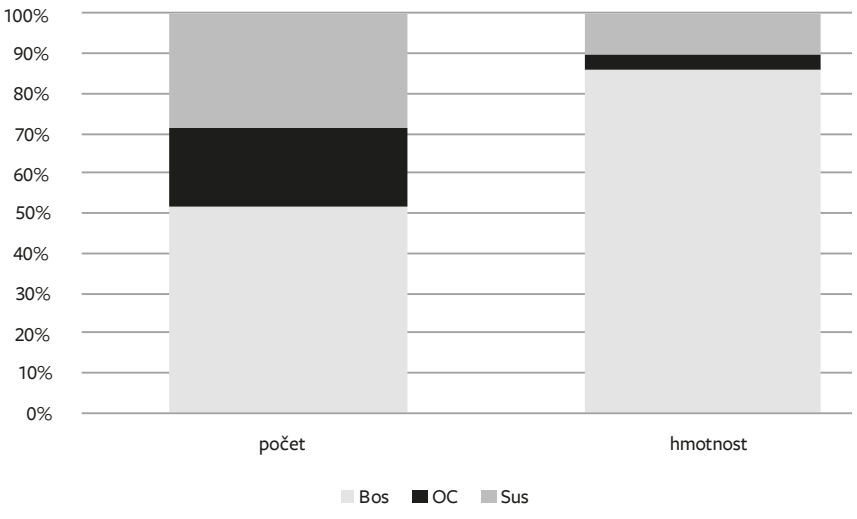

Obr. 1. Relativní početní podíl fragmentů tura, ovce/kozy a prasete (podle počtu a hmotnosti fragmentů). Autorka G. Dreslerová.

Fig. 1. Relative proportion of cattle, sheep/goat, pig

(according to the number and weight of fragments). Author G. Dreslerová.

\begin{tabular}{|c|c|c|c|}
\hline Zvláštnosti & Druh & Kost & Počet \\
\hline \multirow[t]{2}{*}{ artefakt } & Canis & \multirow{2}{*}{ Tibia } & 1 \\
\hline & Ovis/Capra & & 5 \\
\hline \multirow[t]{11}{*}{ okousání } & Sus & Humerus & 1 \\
\hline & Ovis/Capra & Radius & 1 \\
\hline & \multirow[t]{9}{*}{ Bos } & Mandibula & 1 \\
\hline & & Scapula & 1 \\
\hline & & Humerus & 1 \\
\hline & & Radius & 1 \\
\hline & & Pelvis & 1 \\
\hline & & Femur & 1 \\
\hline & & Calcaneus & 1 \\
\hline & & Metatarsus & 2 \\
\hline & & Phalanx & 1 \\
\hline \multirow[t]{2}{*}{ sekání } & \multirow[t]{2}{*}{ Bos } & Mandibula & 1 \\
\hline & & Scapula & 1 \\
\hline \multirow[t]{3}{*}{ řezání } & Canis & Pelvis & 3 \\
\hline & Bos & Mandibula & 1 \\
\hline & Cervus & Metacarpus & 1 \\
\hline spáleno & Cervus & Proc. cornualis & 6 \\
\hline
\end{tabular}

Tab. 2. Typy a četnost tafonomických stop na kostech.

Tab. 2. Types and frequency of taphonomic traces on bones.

\section{Zvířecí skelety v objektech 558 a 578}

Př́tomnost skeletů psů v objektech 558 a 578 výrazně navýšila výskyt kostí této šelmy na lokalitě. Bohužel obrazová dokumentace objektu 558, kde byli uložení dva jedinci, nezachycuje nálezové umístění kostí. $V$ př́ípadě jejich anatomického uspořádání by zde byli deponováni vcelku, nahodilá kumulace by odpovídala druhotné manipulaci s pozůstatky těl zvířat. Další okolnost, která komplikovala analýzu samotnou, bylo společné umístění obou koster do jednoho sáčku, nebot’ obě zvířata byla podobného vzrůstu i věku. K částečnému rozlišení obou jedinců napomohlo odlišné zabarvení kostí. 


\section{Kostra psa I (obj. 558)}

Kostra psa I je dochována v poměrně dobrém stavu. Chybí především drobné kosti předních a zadních končetin (obr. 2). Stav vývoje skeletu odpovídá velikostně dozrálému jedinci, přičemž opotřebení trvalého chrupu není intenzivní. Odhadovaný věk zvířete se pohybuje kolem 4-5 let (Habermehl 1975). Jistou patologii/anomálii lze spatřovat v absenci P1 v dolní čelisti. Nepř́tomnost penisové kosti může indikovat fenku, ovšem nelze vyloučit ani psa, nebot' stav dochování skeletu není stoprocentní. Jedinec byl nižšího středního vzrůstu a jeho kohoutková výška dosahovala kolem $46 \mathrm{~cm}$ (Harcourt 1974). Vzrůstem a robustností se na základě porovnání s ostatním rasami psů (Wagner 1930) blíží whippetovi nebo foxteriérovi (obr. 3). Jako zajímavou hodnotím přítomnost stop po řezání na sedací kosti pánve, což ukazuje na postmortální manipulaci se zvířetem, kdy byly přetnuty pánevní vazy a svalovina (obr. 4). Právě v tomto případě by bylo jistě zajímavé sledovat nálezové rozmístění kostí, které bohužel chybí.

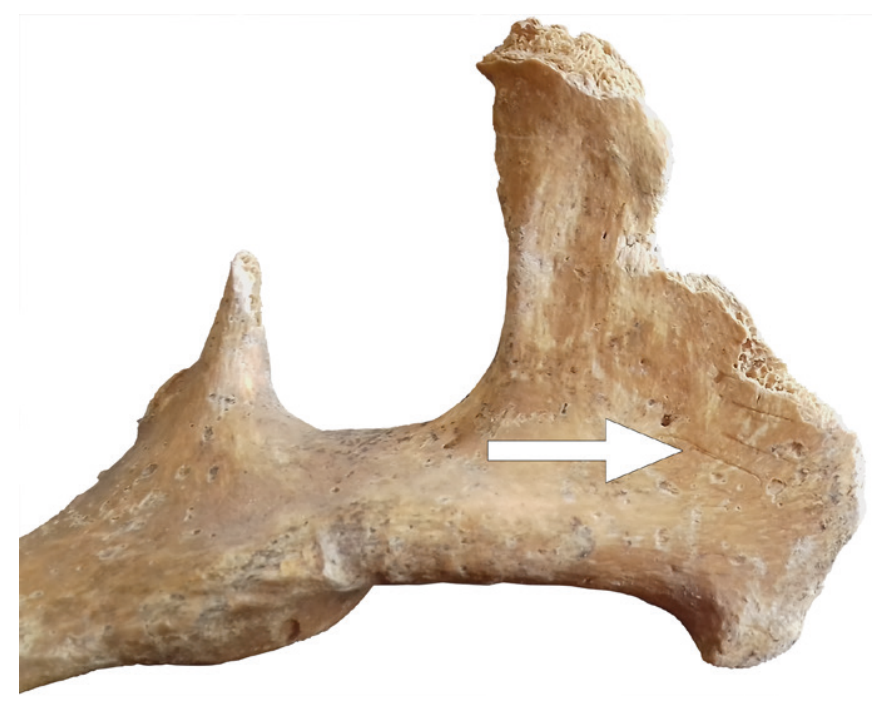

Obr. 3. Stopy řezání na kosti sedací, kostra psa I, obj. 558. Foto G. Dreslerová. Fig. 3. Traces of cutting on sciatic bone, dog skeleton I, feature No. 558. Photo by G. Dreslerová.

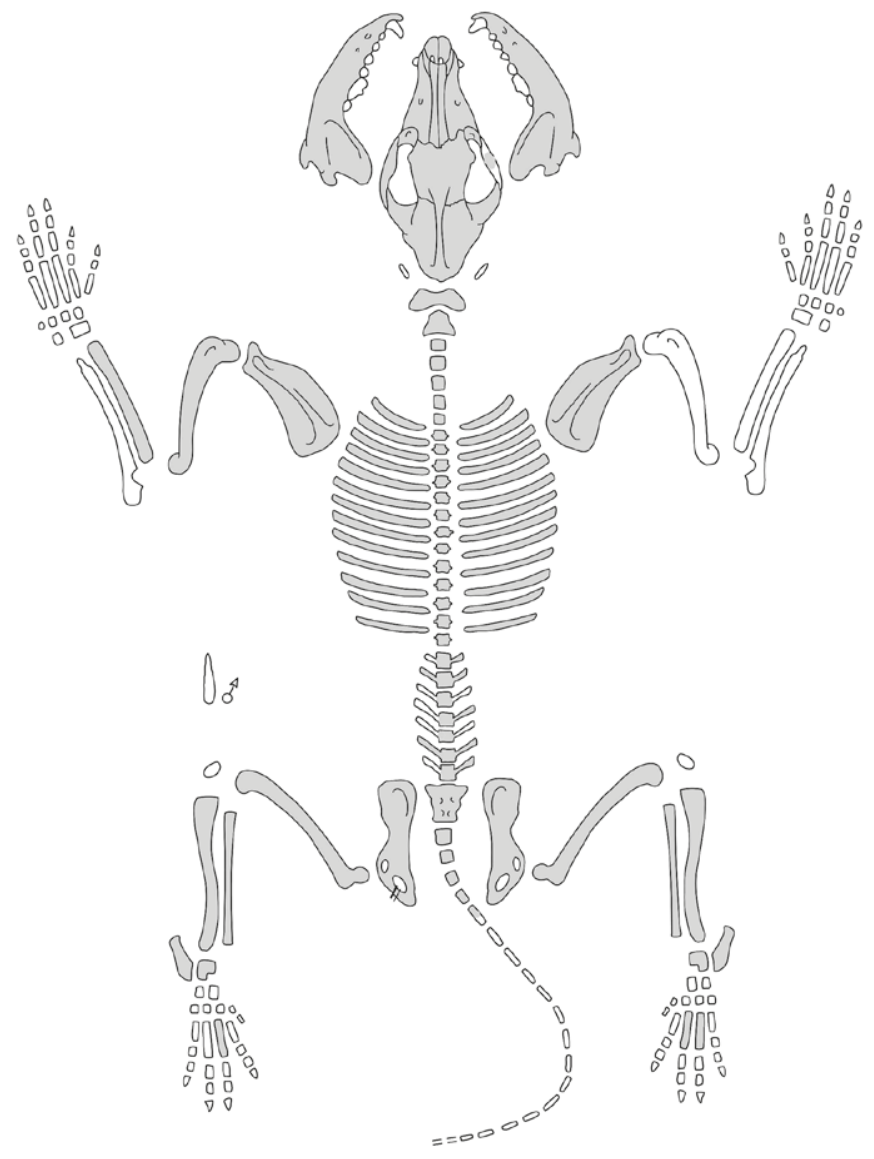

Obr. 2. Stav dochování kostry psa I, obj. 558. Podle Coutureau 2013a ( ArcheoZoo.org. Fig. 2. The state of preservation of dog skeleton I, feature No. 558. From Coutureau 2013a (c) ArcheoZoo.org.

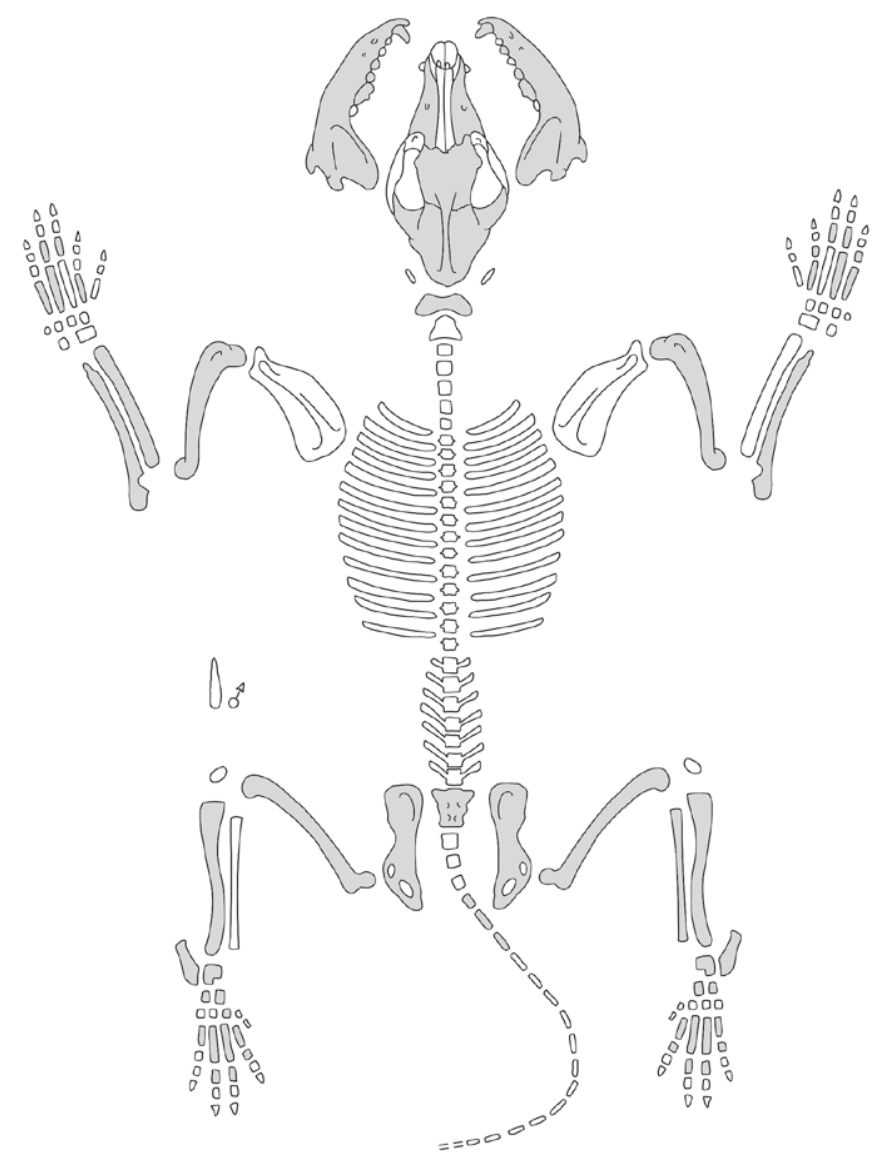

Obr. 4. Stav dochování kostry psa II, obj. 558. Podle Coutureau 2013a ๔ ArcheoZoo.org. Fig. 4. The state of preservation of dog skeleton II, feature No. 558. From Coutureau 2013a (c) ArcheoZoo.org. 


\section{Kostra psa II (obj. 558)}

Kostra psa II z objektu 558 se dochovala v horším stavu. Chybí především kostra páteře a lopatky (obr. 5). Absence kosti penisové může prozrazovat fenku, ale podobně jako u kostry I není situace jednoznačná. Chrup nenese stopy intenzivního obroušení, což ve spojení se stavem dokončeného růstu ukazuje na adultního jedince kolem 4.-5. roku života. Jedinec dosahoval výšky v kohoutku kolem $54 \mathrm{~cm}$ a v porovnání se současnými rasami psů se nejvíce přibližuje dobrmanovi (obr. 3).

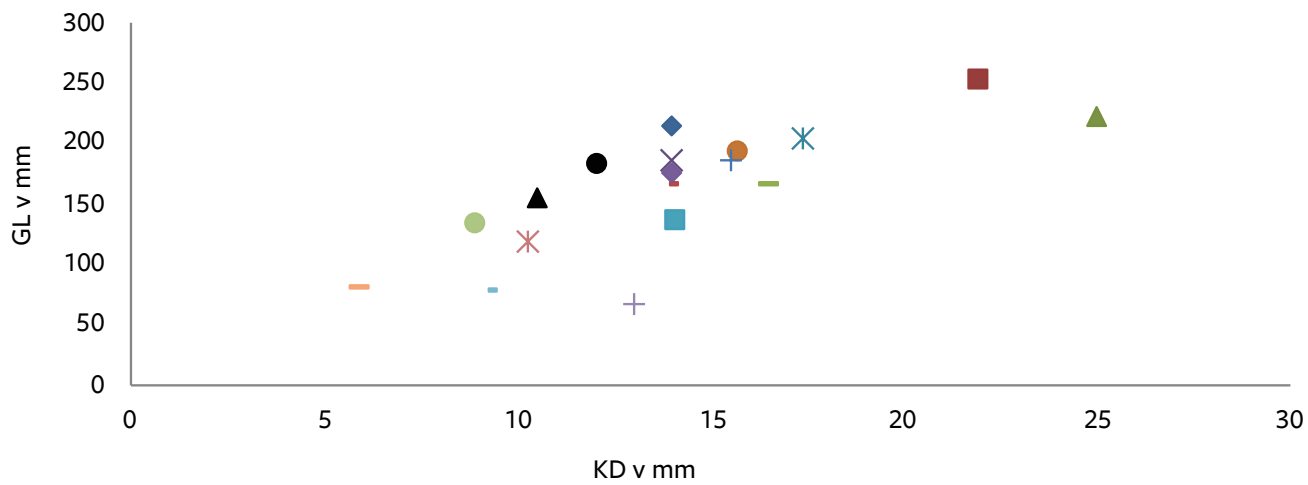

$\begin{array}{ll}\text { - vlkodav } & \text { × dobrman } \\ + \text { setr } & \text { - pudl } \\ \text { - whippet } & \text { - pinč } \\ \text { \ bernardýn } & \text { * ovčák } \\ \text { - dingo } & \text { — buldog } \\ \text { + jezevčík } & \text { \ Medlánky I } \\ \text { - barzoj } & \text { - pointer } \\ \text { - boxer } & \text { * foxterier } \\ \text { - pekinéz } & \text { - Medlánky II }\end{array}$

Obr. 5. Korelace GL a KD kosti vřetenní koster psů I, II a psích plemen (GL - maximální délka kosti, KD - šírka diafýzy kosti). Podle Driesch 1976.

Fig. 5. Correlation of the GL and KD of the radius bone of dog skeletons I, II and dog breeds (GL - maximum bone length, KD - bone diaphysis width) According to Driesch 1976.

\section{Kostra prasete (obj. 578)}

V objektu 578 se nacházely dvě kumulace kostí. První z nich představuje neanatomické rozmístění kostí mladého prasete (obr. 6). Skutečnost, že kosti anatomicky i početně odpovídají kostřre prasete (obr. 7), spolu se shodným určením jejich ontogenetického vývoje naznačuje, že zvíře zde bylo uloženo kompletní, ale již v oddělených anatomických částech. Věk podle vývoje chrupu odpovídá přibližně 6 měsícům (Habermehl 1975, 150). Na skeletu prasete nebyly zaznamenány žádné stopy po řezání nebo sekání. Jejich nepř́ítomnost ovšem neznamená, že by s tělem nebylo manipulováno. Výrazné rozptýlení kostí svědčí o neanatomickém uložení zvířete do objektu.

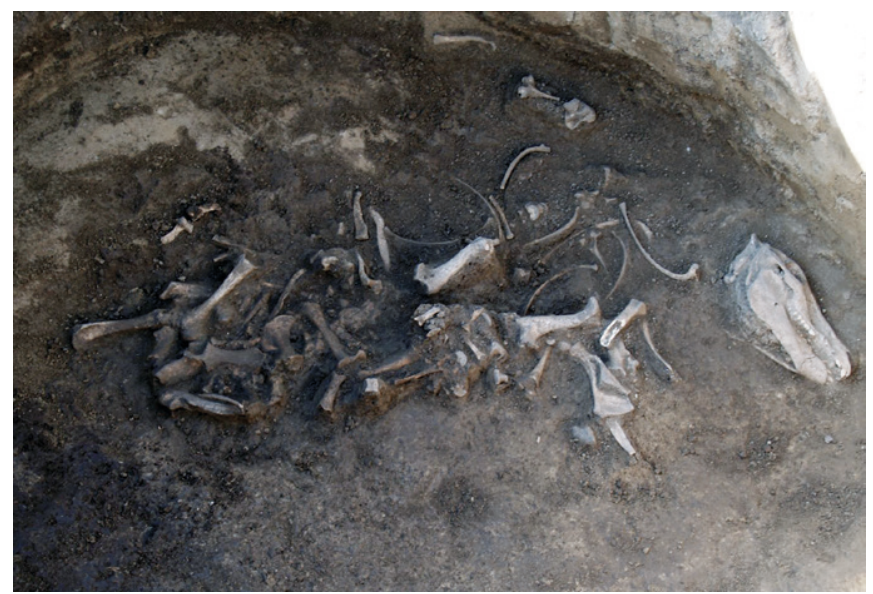

Obr. 6. Nálezová situace kostry prasete, obj. 578. Archiv Ústavu archeologické památkové péče Brno.

Fig. 6. The pig skeleton unearthed, feature No. 578. Archive of the Institute of Archaeological Heritage Brno.

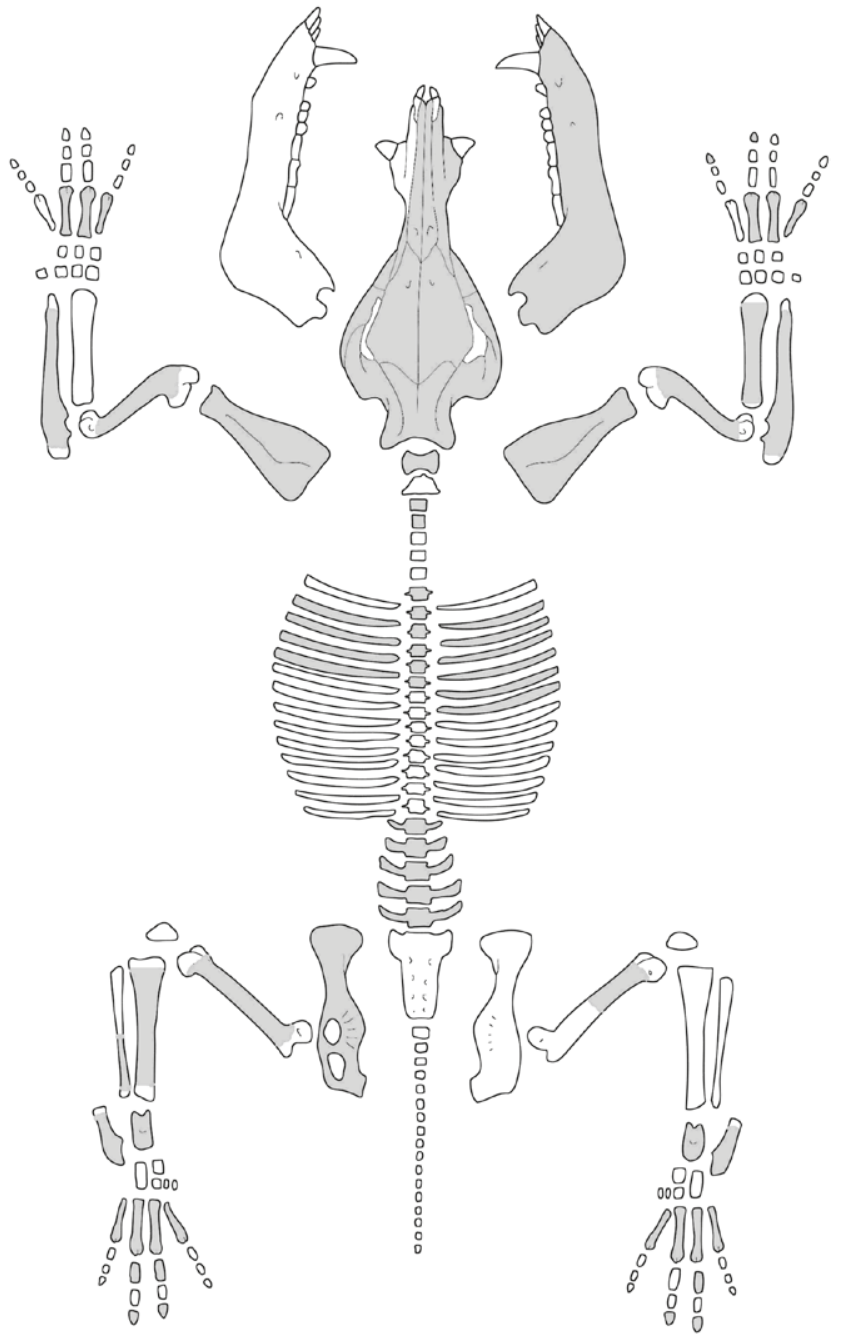

Obr. 7. Stav dochování kostry prasete, obj. 578. Podle Coutureau 2013c (c) ArcheoZoo.org.

Fig. 7. The state of preservation of the pig skeleton, feature No. 578. From Coutureau 2013c ( ArcheoZoo.org. 


\section{Kostra psa III (obj. 578)}

Spolu s prasetem se v koncentraci kostí objevily v sáčku i kosti vzrostlé juvenilní psovité šelmy. Na základě stavu chrupu je odhadovaný věk kolem 4 měsíců (Habermehl 1975, 159). Navzdory poměrně nízkému věku se tento jedinec jeví jako vzrostlý. Přibližná kohoutková výška dosahovala odhadem již $50 \mathrm{~cm}$ (Harcourt 1974), proto nevylučuji, že by se mohlo jednat o vlka. Metrické porovnání se zuby vlka však nebylo vzhledem ke stavu vývoje chrupu takto mladého jedince možné. Tato druhá koncentrace kostí v objektu 578 naznačuje deponovaný skelet zřejmě v anatomické podobě (obr. 8), i když kvalita snímků to plně nezaručuje (obr. 9).

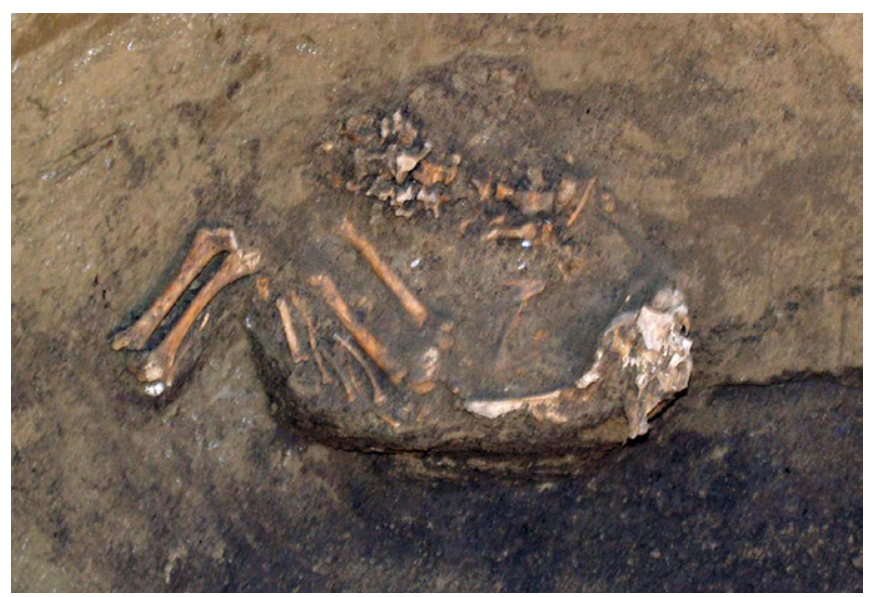

Obr. 8. Nálezová situace kostry psa III, obj. 578. Archiv Ústavu archeologické památkové péče Brno.

Fig. 8. Dog skeleton III, feature No. 578. Archive of the Institute of Archaeological Heritage Brno.

\section{Kostra koně (obj. 541)}

Posledním dochovaným zvířecím skeletem je kostra koně z objektu 541. Jako jediná se nacházela v prokazatelném anatomickém uspořádání (obr. 10, 11). Z dokumentace není ovšem zřejmá orientace uložení kostry. Zvíře spočívá na levém boku s nataženými končetinami. Hlava spolu s krční páteří leží na hrudníku, kam se uvolnila po rozpadu měkkých tkání. Kostra se kromě části lebky dochovala v dobrém stavu (obr. 10). Př́ítomnost špičáků naznačuje hřebce, který podle stavu abraze zubů dosáhl věku kolem 12-13 let (Komárek 1993). Maximální délka dlouhých kostí dovoluje odvodit jeho kohoutkovou výšku kolem $150 \mathrm{~cm}$, což ho podle přehledu vzrůstu prehistorických koní řadí do kategorie vyšší než střední (Vitt 1952).

Z patologických projevů je nutné zmínit výskyt exostózy na proximálním prstním článku a zhojenou zlomeninu žebra. V oblasti hrudní páteře srostly trnové výběžky (asi 6 hrudních obratlů), tzv. „kissing spines syndrome“(Hanzelková 2018). Toto onemocnění je v současné době diagnostikováno u koní pomocí rentgenových snímků již jako poslední stádium potíží se zády a jejich záněty. Za př́činu jsou označovány skoky, skoky přes překážky, pády. S vysokým tlakem v oblasti hřbetu se zřejmě potýkal i tento zde deponovaný jezdecký kůň.

Za další anomálii lze označit výrazné obroušení třenového zubu (obr. 12). Bohužel nebyl dochován protilehlý zub, který by mohl důvod této nerovnoměrnosti vysvětlit. Podobný nález je spojován s využitím udidla a jeho působením v tlamě koně (Bartosiewicz, Gál 2013, 134, obr. 110).

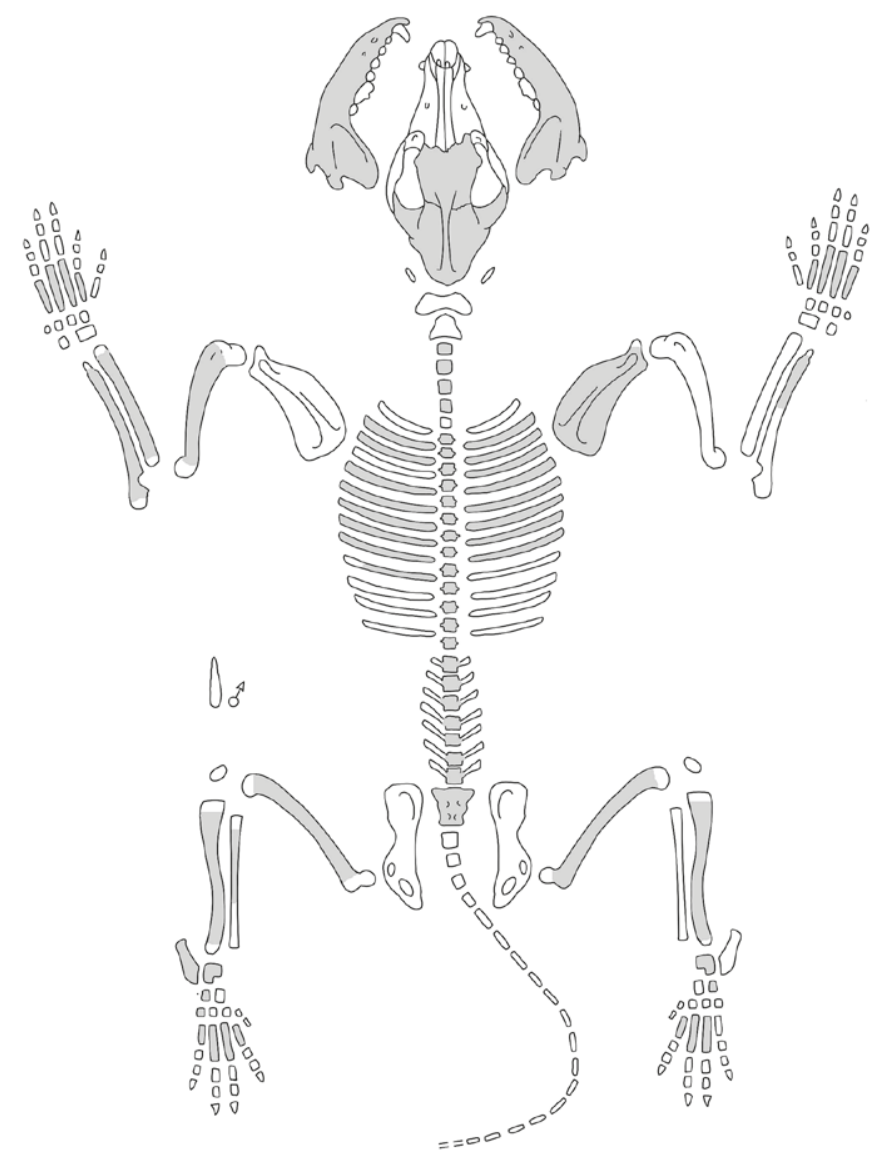

Obr. 9. Stav dochování kostry psa III, obj. 578. Podle Coutureau 2013a (c) ArcheoZoo.org.

Fig. 9. The state of preservation of dog skeleton III, feature No. 578. From Coutureau 2013a (c) AcheoZoo.org.

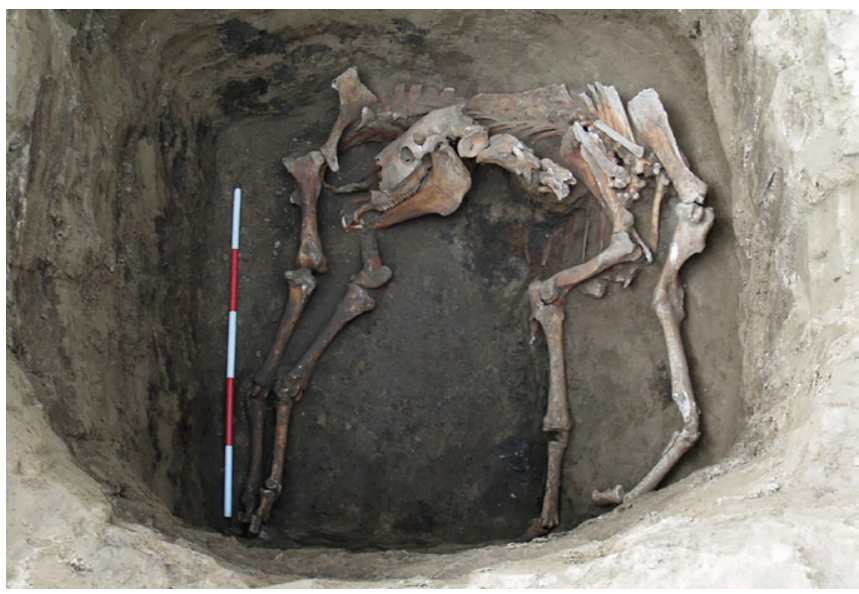

Obr. 10. Nálezová situace skeletu koně, obj. 541. Archiv Ústavu archeologické památkové péče Brno.

Fig. 10. The horse skeleton unearthed, feature No. 541. Archive of the Institute of Archaeological Heritage Brno. 


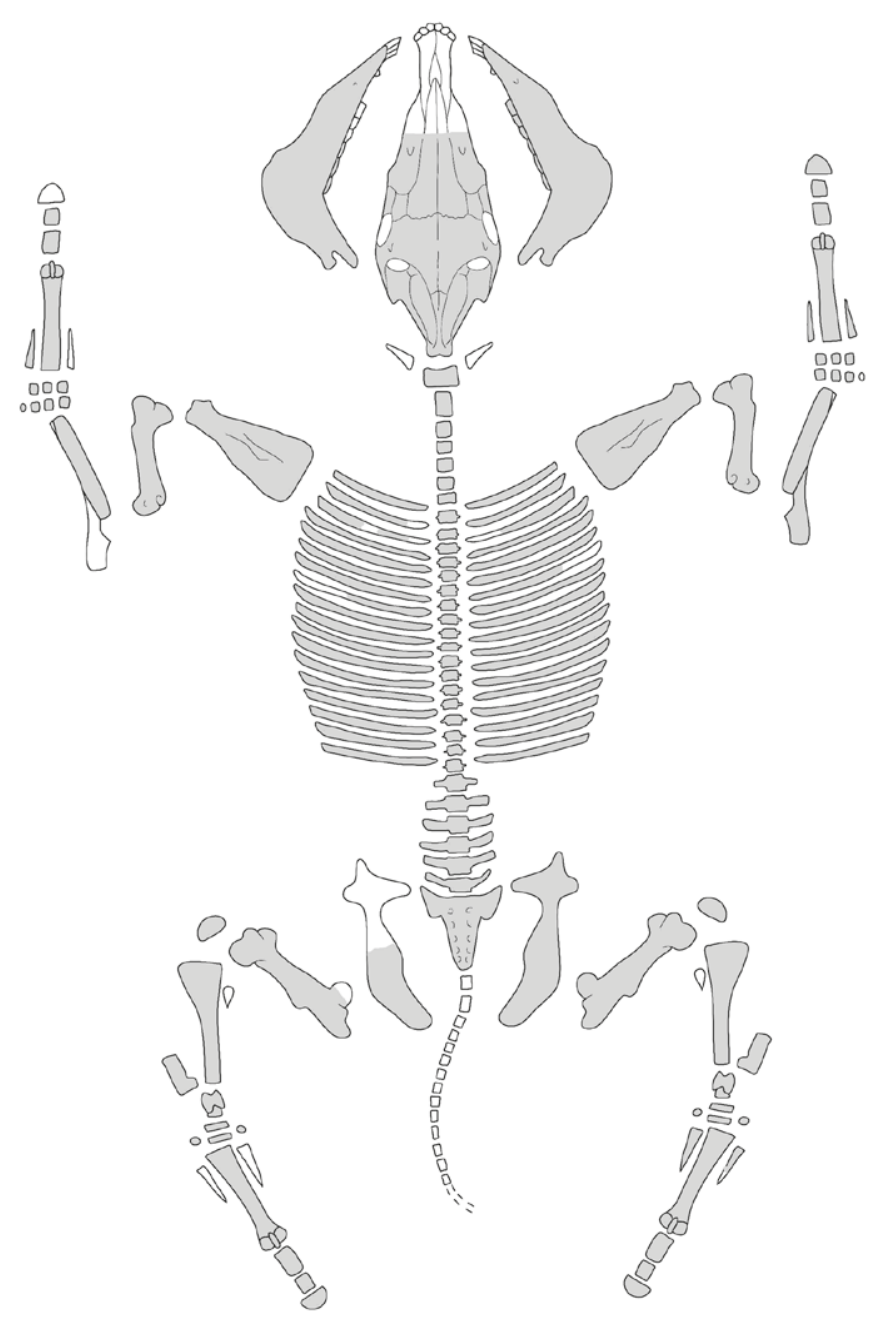

Obr. 11. Stav dochování kostry koně, obj. 541. Podle Coutureau 2013b (c) ArcheoZoo.org

Fig. 11. The state of preservation of the horse skeleton, feature No. 541 From Coutureau 2013b (c) ArcheoZoo.org.

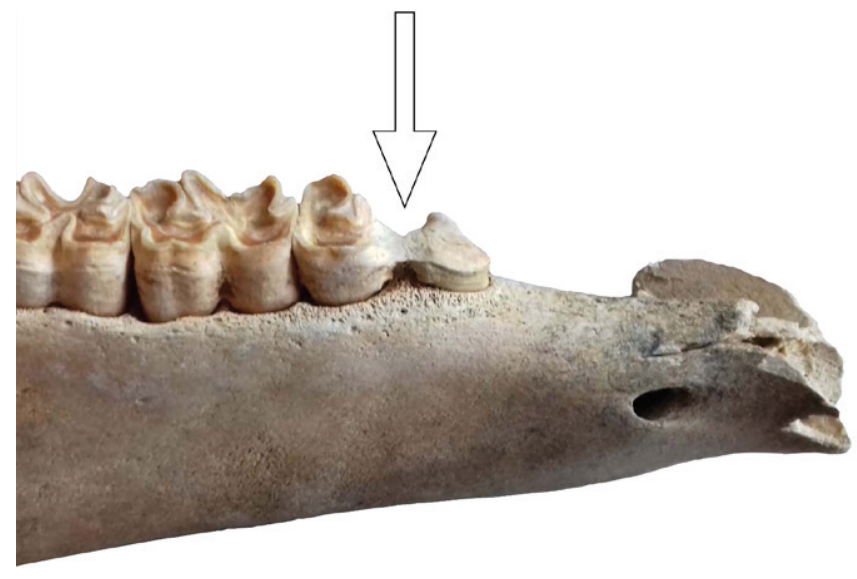

Obr. 12. Intenzivní abraze třenového zubu koně, obj. 541. Foto G. Dreslerová. Fig. 12. Intensive abrasion of the horse's molar tooth, feature 541. Photo by G. Dreslerová.

\section{Krátký exkurs k deponiím koní a psů doby hradištní}

Jak se jeví pohřeb koně a psů z Medlánek ve srovnání s dalšími podobnými nálezy na Moravě v době hradištní? Nabízí se uvést jejich stručný přehled. Samotné detailní zhodnocení tohoto jevu, nyní obohaceného o nové nálezové situace, si v budoucnu žádá komplexní zpracování zohledňující veškeré dostupné faktory.

Počátky pohřbívání koní jsou ve střední Evropě spojovány převážně s příchodem nomádských etnik (Dostálová 2012, 42), ovšem v hektickém období stěhování národů se se samostatnými hroby koní setkáváme rovněž i v blízkostech mužských hrobů Langobardů (Bóna, Horváth 2009, 110-111; Kováčová 2013, 241). Pro avarské období je příznačný výskyt tzv. jezdeckých hrobů, kdy je spolu s člověkem pohřben i kủň. Na pohřebištích ve slovenském Komárně (IV, VI, XIII a IX) bylo zaznamenáno 103 jezdeckých hrobů z celkového počtu 240. Na dalších lokalitách z tohoto období a oblasti jihozápadního Slovenska (napřr. Košice-Barca, Bernolákovo, Holiare, Nové Zámky, Šal’a, Šebastovce, Štúrovo, Virt a Žitavská Tóň) dosahuje podíl jezdeckých hrobů kolem 10 \% (Zábojník 2004, 33-37, 78-95). Souborné osteologické hodnocení prozrazuje, že větší část (75\%) pohřbených koní tvořili jedinci mladší 9 let a polovina z nich vykazuje patologické změny na páteři, což souvisí s jejich jezdeckým využitím (Ambros, Müller 1974, 83). Kohoutková výška těchto koní se pohybovala v rozmezí od 124 do $143 \mathrm{~cm}$. Za poměrně specifický projev pohřebního ritu lze označit nálezovou situaci na avarském pohřebišti ve Tiszafüredu (Garam 1995, 171). V rámci jeho areálu se kromě lidských hrobů nacházelo 70 hrobů výlučně koní, které se velikostí hrobové jámy shodovaly s mužskými hroby. $V$ př́padě šesti z nich byla prokázána přítomnost dřevěné konstrukce. Výskyt již jen částí skeletů koní (lebky, končetiny, páteř) v hrobech byl zpočátku připisován výlučně staromad'arskému etniku; pomineme-li starší období, objevuje se tento způsob částečného uložení skeletu koně spolu s jezdcem již v avarském prostředí (Zábojník 2004, 37). Ze staromad’arského období je pro oblast Slovenska doposud archeozoologicky zpracováno 17 těchto zvířecích jedinců (Miklíková 2006, 356-357) a podobně jako ve starším období i zde převažují mladší zvířata. Ze slovanského pohřebiště v Borovcích jsou doloženy dva hroby koní poměrně vysokého věku 18 a 20 let (Staššíková-Štukovská 2001, 376-378).

Proti tomu výskyt koster koní na sídlištích je ojedinělý, což platí i v př́ípadě v tomto směru specifické lokality Bajč, kde se objevují deponované kostry koní v blízkosti hrobů (Miklíková, Ruttkay 2003, 214).

V českých zemích není přítomnost deponovaných koster koní nebo jejich částí na sídlištích nebo i pohřebištích doby hradištní jevem neobvyklým, ale ani četným. V Čechách je evidováno devět lokalit doby hradištní, které ovšem pocházejí ze starých archeologických výzkumů a postrádají dostatečné množství nálezových informací (Hrádek u Sudoměře, Libušín u Kladna, Běchary, Dobroměřice, Ledvice u Duchcova, Libice nad Cidlinou, Řestoky u Chrudimi, Svobodné Dvory, Přerov nad Labem; Krumphanzlová 1972). Nověji byla zaznamenána torza koster koní v prostoru příkopu raně středověkého hradu ve Staré Boleslavi. Jejich přítomnost zde byla interpretována jako důsledek odklízení mršin (Kyselý 2003, 311-334). Na Moravě je zaznamenáno spolu s prezentovanou situací v Medlánkách 15 lokalit s výskytem převážně kompletního deponovaného skeletu koně (Břeclav - Pohansko, Dolní Věstonice - Na Pískách, Držovice, Krčmaň - Za hatí, Letonice, Náměšt na Hané - Valník, Olomouc - Nemilany, Prušánky, Šlapanice; tab. 3, obr. 13). Některé z těchto nálezů byly podrobeny i archeozoologickému zkoumání, které zachytilo v několika případech patologické změny způsobené vyšší fyzickou zátěží, a to jak na páteři (Držovice, Brno-Medlánky), tak na končetinách (Nemilany). 


\begin{tabular}{|c|c|c|c|c|c|c|c|}
\hline & Lokalita & Typ & Canis & Equus & Homo & Datace & Literatura \\
\hline 1 & Brno-Medlánky & sídliště & $2(3)$ & 1 & & středoH & Benech 2019, 113 \\
\hline 2 & Břeclav-Líbivá & sídliště & 5 & & & středoH & Macháček 2001, 48 \\
\hline 3 & Břeclav - Pohansko & hradiště & 8 & 5 & & středoH & Vignatiová 1992, 44; Přichystalová 2013, 15 \\
\hline 4 & Kostice - Zadní hrúd & sídliště & 2 & & & staroH-mladoH & Dreslerová 2018, 59 \\
\hline 5 & Břeclav - Stará Břeclav 2 & hrob s jezdcem & & 1 & 1 & středoH & Lutovský 2001, 41 \\
\hline 6 & Držovice & hrob s jezdcem & & 2 & 1 & středoH & Fojtík 2014, 175 \\
\hline 7 & Dolní Věstonice - Na Pískách & pohřebiště, hrob s jezdcem & & 2 & 1 & středoH & Poulík 1949, 130; Jarošová et al. 2012, 215 \\
\hline 8 & Krčmaň - Za hatí & pohřebiště + sídliště & & 1 & & středoH & Tajer 2001, 214 \\
\hline 9 & Letonice & kultovní objekt & & 1 & & středoH & Drozdová, Šedo 2004, 224 \\
\hline 10 & Mikulčice - Klášteřisko & pohřebiště & & 3 & & středoH & Klanica 1985, 476 \\
\hline 11 & Mikulčice - Kostelisko & pohřebiště & & 1 & & středoH & Klanica 1987, 36 \\
\hline 12 & Mutěnice - Zbrod & sídliště & & 1 & & staroH-středoH & Klanica 2008, 117 \\
\hline 16 & Náměšť na Hané - Valník & pohřebiště & & 1 & & staroH-středoH & Dohnal 1991, 221 \\
\hline 13 & Olomouc - Nemilany 1 & pohřebiště & & 3 & & středoH & Kalábek 2009, 150; Dreslerová 2014, 175 \\
\hline 14 & Prušánky & pohřebiště & & 1 & & 8.-11. stol. & Klanica 2006, 120 \\
\hline 15 & Šlapanice & pohřebiště & & 2 & & stř̌edoH & Geisler 2010, 475 \\
\hline 16 & Velké Bílovice & pohřebiště + sídlištní objekty & 1 & & & středoH & Měřínský 1984, 39 \\
\hline 17 & Bajč & sídliště + hroby & 13 & 6 & & 8.-11. stol. & Miklíková, Ruttkay 2003, 207 \\
\hline 18 & Borovce & pohřebiště & & 2 & & 8.-11. stol. & Staššíková-Štukovská 2001, 376 \\
\hline
\end{tabular}

Tab. 3. Seznam lokalit raného středověku s výskytem koster koně a psa, zkratky: staroH - starohradištní, středoH - středohradištní.

Tab. 3. List of the early medieval sites with finds of horse and dog skeletons, abbreviations: staroH - Old Hillfort period (650-800), středoH - Middle Hillfort period (800-950).

V případě deponování psů se s jejich četným výskytem setkáváme v průběhu doby římské, kdy byli umistováni přímo do lidských obydlí nebo v jejich blízkosti (Beneš, Nývltová Fišáková 2009). Z doby hradištní známe několik málo těchto případů, pět z prostoru jižní Moravy, včetně Medlánek (Dreslerová 2018, 71-74; Drozdová, Šedo 2004, 224; Macháček 2001, 48).

Předložený soupis pohřbů psů a koní uvádí dataci, typ lokality i četnost skeletů. V př́ípadě umístění skeletu v blízkosti hrobů i sídlištních objektů označuji tuto situaci jako sídliště. S vysokým počtem převažují lokality doby středohradištní. Jednoznačně datovaná lokalita s výskytem skeletu koně nebo psa ve starohradištním období v českých zemích prozatím není evidována; výjimku tvoří výše uvedené neúplné skelety ze Staré Boleslavi.

Zvířecí skelety mírně převažují na pohřebištích. Při zohlednění daného druhu zvírete vyplývá, že s deponovanými skelety psů se setkáváme výlučně na sídlištích. Naproti tomu kostry koní se vyskytují především v blízkosti lidských hrobů. V prŕípadě výskytu pohřbů koní mimo areál pohřebišt se místu připisuje kultovní funkce, nebot? v jejich blízkosti se vyskytují i lidské kostry nebo jejich části (Letonice, Mikulčice - Klášteřisko, Břeclav Pohansko). Rovněž v Medlánkách byla ve vzdálenosti cca 40 metrů od objektu s koněm nalezena kostra člověka, ovšem vhozená do zásobnicové jámy (Benech 2019, 121). Určitou podobnost lze spatřovat se sídlištěm v Bajči. Na této slovenské lokalitě bylo nalezeno velké množství zvířecích skeletů, a to nejen koní a psů, ale i dalších hospodářských zvířat. Vysokého podílu dosahovali ovšem velmi mladí jedinci, plody nevyjímaje (Miklíková, Ruttkay 2003, 212). Rovněž počet patologických změn na těle zvírat zde byl poměrně vysoký. Př́ícina uložení těl zvíruat na lokalitě v Bajči je připisována kultovním účelům, kdy zvířata plnila úlohu obětiny nadpřirozeným silám, případně doprovodu mrtvých válečníků, jejichž hroby se nacházely v blízkosti koňských pohřbů (Miklíková, Ruttkay 2003, 214).

Pro samotnou interpretaci nálezů kompletních zvířecích skeletů v archeologických situacích je důležité zjistit příčinu této depozice. Obecně se můžeme u zvířecích skeletů setkat bud' s pietním uložením, kdy je tělo stylizováno jako spící, spočívající na boku, nebo mohou být dochované zvírecí skelety do objektu vhozeny, vtaženy, což prozrazuje nahodilé rozmístění končetin, rotace podélné osy těla atd. V blízkosti archeologických lokalit se ovšem objevují i zvířecí kostry, s jejichž uložením nemá člověk co do činění, nebot zvíře, např. liška, mohlo zemřít v noře v důsledku nemoci, umrznutí apod.

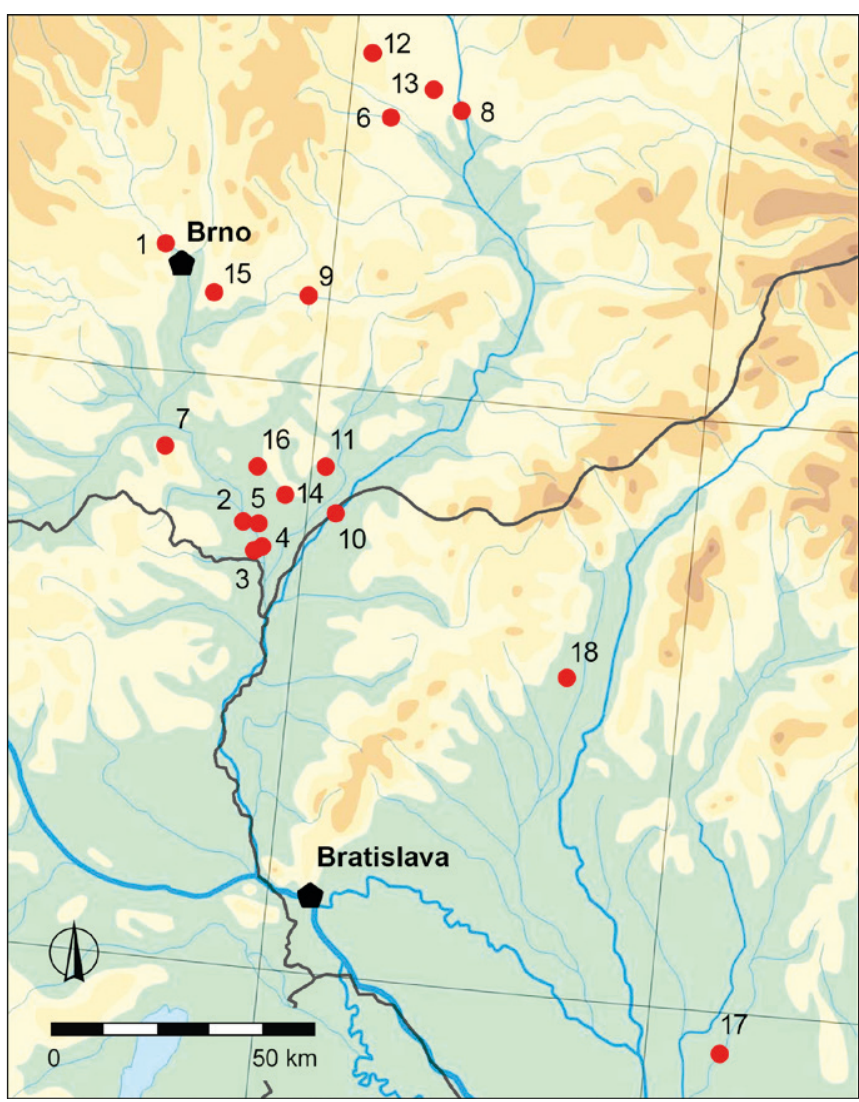

Obr. 13. Mapa výskytu koster koní a psů raného středověku na Moravě a Slovensku. Autor P. Dresler.

Fig. 13. Early medieval sites with skeletons of horses and dogs in Moravia and Slovakia. Author P. Dresler 
Kůň jako zástupce domácí fauny patřil v době hradištní k jednoznačně největším zvířatům. Pro toto časové období jsou uváděny kohoutkové výšky v rozmezí 130-150 cm (Dreslerová 2018, 59; Kratochvíl 1969; Novotný 1966; Peške 1985, 214). S odhadovanou hmotností 250-350 kg představovalo jeho tělo objemné břemeno a manipulace s ním byla jistě fyzicky náročná. Zvíře mohlo být usmrceno v bezprostřední blízkosti objektu určeného pro jeho pohřbení. V tomto směru se setkáváme bud' s deponií koně v objektu vykopaném na „míru“, nebo s objektem, který původně plnil jiný účel a $\mathrm{k}$ pohřbu koně byl využit druhotně (Přichystalová 2013,26). Primární funkce takového objektu výrazně ovlivňuje samotný způsob uložení koně a dle mého pozorování mohou být trojího druhu: prvním je volné uložení koně na levý či pravý bok, kdy se tělo nemusí výrazně přizpůsobovat velikosti vykopané jámy. V tomto př́padě jsou nohy volně uložené a hlava zaujímá přirozenou polohu (Dolní Věstonice - Na Pískách, obj. 452; Mikulčice - Klášteřisko; Mikulčice - Kostelisko; Prušánky). Druhou skupinu představují těla umístěná do menších objektů, v důsledku čehož jsou končetiny a hlava koně umístěny do stylizovaných pozic (Brno-Medlánky, Břeclav - Pohansko/dále Pohansko/, hrob H 7 a obj. 65, Držovice H1, Olomouc - Nemilany H 35, H 36 a H 38). Třetí, poslední skupinu představují těla vhozená nebo vtažená do objektů bez následné úpravy (Pohansko, žárové pohřebiště, obj. 10; Držovice, obj. 652; Letonice 3/87).

Způsob uložení koně z Medlánek by mohl být v případě tohoto členění zařazen ke druhé skupině, nebot depozice těla byla limitována prostorem objektu, zásobnice. Ačkoliv jsou končetiny koně umístěny v natažené poloze, poloha hlavy svědčí o jejím vměstnání ke stěně objektu a následném spočinutí na hrudi zvířete. Je otázkou, zda lze tohoto způsobu uložení dosáhnout i nahodilým vhozením mrtvého těla do hlubokého objektu. S podobným umístěním hlavy na hrudníku se setkáváme i na pohřebišti v Borovcích, kde hlava ležela rovněž na hrudi (Staššíková-Štukovská 2001, 378) anebo na sídlišti v Bajči (Miklíková, Ruttkay 2003, 208, obr. 5).

Vzhledem k částečné absenci obrazové dokumentace koster psů z Medlánek nelze tyto skelety blíže interpretovat. Přítomnost stop po řezání na pánevních kostech jednoho z nich nicméně ukazuje na postmortální manipulaci s mrtvým tělem. I v př́padě nálezů koster psů z doby hradištní se setkáváme se třemi typy uložení. První představují psi umístění do objektů v anatomickém uspořádání (Pohansko, obj. 69; Břeclav-Líbivá obj. 5, 76). Druhou skupinou jsou skelety deponované na původní podlaze obydlí, v anatomickém dochování (Kostice - Zadní hrúd, obj. 70, 178). Třetí poslední skupinu představují skelety již v neúplné anatomické podobě (Pohansko, obj. 18, 29; Břeclav-Líbivá obj. 88).

Dochování takřka kompletních koster psů z Medlánek s jejich umístěním v objektech naznačuje zařazení do prvé nebo třetí skupiny nálezů. Ovšem př́tomnost prokazatelných stop po manipulaci s tělem zvířete nevylučuje ani rituální zacházení nebo i samotnou konzumaci jeho masa.

\section{Shrnutí}

Význam osteologických nálezů slovanského sídliště v Brně-Medlánkách tkví především ve vyšší koncentraci zvířecích skeletů. Zjištěný věk žádného z nich nenaznačuje, že by zvířata zemřela stářím. Byla spíše zabita a vzhledem $\mathrm{k}$ absenci okusů na kostech v krátké době po usmrcení deponována. Přítomností kostry koně se situace na sídlišti v Medlánkách vymyká z běžného standardu raně středověkých lokalit v Čechách a na Moravě. Jistou podobnost lze nacházet v Letonicích (kůň, kur) nebo slovenské Bajči, kde se ojedinělé hroby vyskytovaly. V př́ípadě Bajče se kostra koně rovněž nacházela v zásobní jámě. Nález kostry koně na sídlišti v Medlánkách představuje uložení mrtvého koně do objektu, který původně sloužil jinému účelu.
Ačkoliv samotné anatomické uspořádání dochovaného skeletu koně nenaznačuje nahodilé uložení, nelze jej vzhledem k druhotnému způsobu využití objektu vyloučit. Archeozoologická analýza nicméně potvrdila intenzivní jezdecké využití tohoto koně - hřebce, jenž byl po své smrti přemístěn za pomoci několika lidí do zahloubeného objektu. Tato činnost mohla být vedena jak snahou zabránit rozvlečení mrtvého těla šelmami, tak i pietním zacházením s tělem ceněného zvíruecího průvodce, společníka slovanského jezdce.

Výskyt koster psů v objektech na sledovaném sídlišti je srovnatelný s nálezy na hradisku Pohansko a jeho blízkém okolí (Pohansko - jižní předhradí; Břeclav-Líbivá; Kostice - Zadní hrúd). Bohužel bližší interpretace příčiny uložení psů na sídlišti v Medlánkách nejsou vzhledem $\mathrm{k}$ absenci obrazové dokumentace možné. Skutečnost, že na pánevních kostech jednoho z psů byly zachyceny stopy po řezání, ukazuje na posmrtnou manipulaci s tělem zvířete. Toto zacházení mohlo souviset jak s konzumací masa, tak i s př́ipravou zvířecí obětiny nadpřirozeným silám. Podle archeozoologického určení kostěné industrie z této lokality je zřejmé, že pozůstatky psa bývaly využity pro řemeslné zpracování.

\section{Poděkování}

Práce byla podpořena projektem MUNI/A/0839/2019 „Archeologické terénní prospekce, exkavace, dokumentace a muzejní prezentace IX“.

\section{Literatura}

Ambros, C., Müller, H. H. 1974: Frühgeschichtliche Pferdeskelettfunde aus dem Gebiet der Tschechoslowakei. Archaeologica Slovaca Fontes XIII. Bratislava: Veda.

Bartosiewicz, L. Gál, E. 2013: Shuffing Nags, Lame Ducks. Oxford: Oxbow Books.

Benech, J. 2019: Slovanské sídlisko v Brne-Medlánkach [online]. Rkp. magisterské diplomové práce. Brno: Masarykova univerzita. Filozofická fakulta. Ústav archeologie a muzeologie. Uloženo: Archiv závěrečných prací Masarykovy univerzity [cit. 2020-06-07]. Dostupné z https://is.muni.cz/th/psgq1/.

Beneš, Z., Nývltová Fišáková, M. 2009: „Pohřby psư“ na sídlištích doby římské v Čechách: současný stav poznání. In: M. Karwowski, E. Droberjar (eds.): Archeologia Barbarzyńców 2008: powiazania $i$ kontakty $w$ świecie barbarzyńskim. Collectio Archaeologica Ressoviensis Tomus XIII. Rzeszów: Institut Archeologii Uniwersytetu Rzeszowskiego, 531-542.

Bóna, I., Horváth, J. B. 2009: Langobardische Gräberfelder in West-Ungarn. Budapest: Magyar Nemzeti Múzeum.

Coutureau, M. 2013a: ArchéoZoothèque. Exploded skeletons. Canidae. Canis familiaris. [online]. In: ArchéoZoo. Informations et ressources en archéozoologie. (C2020. [cit. 2020-07-01]. Dostupné z: https:// www.archeozoo.org/archeozootheque/picture/2946

Coutureau, M. 2013b: ArchéoZoothèque. Exploded skeletons. Equidae. Equus caballus. [online]. In: ArchéoZoo. Informations et ressources en archéozoologie. (C2020. [cit. 2020-07-01]. Dostupné z: https:// www.archeozoo.org/archeozootheque/picture/2949

Coutureau, M. 2013c: ArchéoZoothèque. Exploded skeletons. Suidae. Sus scrofa. [online]. In: ArchéoZoo. Informations et ressources en archéozoologie. (C2020. [cit. 2020-07-01]. Dostupné z: https:// www.archeozoo.org/archeozootheque/picture/2951

Dohnal, M. 1991: Slovanská pohřebiště na Olomoucku. Časopis Slezského zemského muzea. Série B - vědy historické 40(3), 220-246.

Dostálová, K. 2012: Využití koní v raném středověku [online]. Rkp. diplomové práce. Univerzita Karlova v Praze. Filozofická fakulta, Ústav pro pravěk a ranou dobu dějinnou. [cit. 2020-04-05]. Uloženo: Depozitář závěrečných prací Univerzity Karlovy v Praze. Dostupné z: https://is.cuni.cz/webapps/zzp/detail/65092/ 
Dreslerová, G. 2014: Nemilany - hroby koní - archeozoologická analýza. In: R. Přichystalová, M. Kalábek (eds.): Raně středověké pohřebiště Olomouc - Nemilany: katalog. Brno: Masarykova univerzita, 175-189.

Dreslerová, G. 2018: Sociální a ekonomická stratifikace obyvatelstva raně středověkého centra na základě archeozoologických analýz [online]. Rkp. disertační práce. Brno: Masarykova univerzita. Filozofická fakulta. Ústav archeologie a muzeologie. Uloženo: Archiv závěrečných prací Masarykovy univerzity [cit. 2020-04-06]. Dostupné z: https://is.muni.cz/th/x7wgg/GabrielaDreslerova.pdf?info=1.

Driesch, A. von 1976: Das Vermessen von Tierknochen aus Vor-und Frühgeschichtlichen Siedlungen. München: Institut für Paläoanatomie Domestikationsforschung und Geschichte der Tiermedizin.

Drozdová, E., Šedo, O. 2004: Úvodní informace o objektu 6/86 s pohozenými lidskými i zvírecími kostrami z doby velkomoravské v Letonicích. In: V. Hašek, R. Nekuda, M. Ruttkay (eds.): Ve službách archeologie V. Brno: Muzejní a vlastivědná společnost, 223-235.

Fojtík, P. 2014: Držovice na Moravě, cihelna 2014, „Náhodný nález lidských kosterních pozůstatkư v hliníku bývalé cihelny Konečného a Nedělníka, hranice parc. č. 216/1 a 216/2, k. ú. Držovice na Moravě, okr. Prostějov“. Rkp. nálezové zprávy, č. akce 101/14. Uloženo: Archiv Ústavu archeologické památkové péče Brno, v. v. i.

Garam, É. 1995: Das awarenzeitliche Gräberfeld von Tiszafüred. Budapest: Akadémai Kiadó.

Geisler, M. 1987: Záchranný výzkum v Brně - Medlánkách (okr. Brno-město). Přehled výzkumů 1984, 74-75.

Geisler, M. 2008: Brno (k. ú. Královo Pole a Medlánky, okres Brno-město). Přehled výzkumů 49, 393-394.

Geisler, M. 2010: Šlapanice u Brna. Přehled výzkumů 51, 475-476.

Habermehl, K.-H. 1975: Die Altersbestimmung bei Haus- und Labortieren. Berlin: Parey.

Hanzelková, V. 2018: Dotyk trnových výběžků aneb Kissing Spines Syndrom. Rkp. bakalářské práce. Mendelova univerzita v Brně. Agronomická fakulta. Ústav morfologie, fyziologie a genetiky zvírat. Uloženo: Knihovna Mendelovy univerzity v Brně. Dostupné také z: https://is.mendelu.cz/zp/index. pl?podrobnosti $=86659$.

Harcourt, R. A. 1974: The dog in prehistoric and early historic Britain. Journal of Archaeological Science 1(2), 151-175.

Jarošová, I., Fojtová, M., Tvrdý, Z. 2012: Antropologická analýza raně střredověké populace z Dolních Věstonic - Na Pískách. Anthropos: studies in anthropology, palaeoethnology and quaternary geology vol. 34, N. S. 26. Brno: Moravské zemské muzeum.

Kalábek, M. 2009: Hradištní lokality objevené na trase dálničního obchvatu Olomouce (1999-2005). In: P. Dresler, Z. Měř́nský (eds.): Archeologie doby hradištní v České a Slovenské republice. Brno: Masarykova univerzita, 150-157.

Klanica, Z. 1985: Mikulčice-Klášteřisko. Památky archeologické LXXVI, 474-539.

Klanica, Z. 1987: Vorbericht über die Ergebnisse der 32. Grabungssaison in Mikulčice (Bez. Hodonín). Přehled výzkumů 1985, 35-36, Tab. 5-6.

Klanica, Z. 2006: Nechvalín, Prušánky. Čtyři slovanská pohřebiště, díl I. Brno: Archeologický ústav AV ČR Brno.

Klanica, Z. 2008: Mutěnice-Zbrod: zaniklé slovanské sídliště ze 7.-10. století. Brno: Archeologický ústav AV ČR Brno.

Komárek, V. 1993: Odhad věku koně. Praha: Institut výchovy a vzdělávání ministerstva zemědělství ČR.

Kováčová, L. 2013: K sociálnym otázkam longobardských pohrebísk na vybraných lokalitách na strednom Dunaji. Zborník Slovenského národného múzea CVII. Archeológia 23, 237-244.
Kratochvíl, Z. 1969: Die Tiere des Burgwalles Pohansko. Praha: Academia.

Krumphanzlová, Z. 1972: Die Ausstattung der Burgwallzeitfriedhöfe und ihre rituelle Bedeutung. In: J. Poulík (ed.): Vznik a počátky Slovanu VII. Praha: Academia, 179-207.

Kyselý, R. 2003: Savci (Mammalia) z raně středověkého hradu Stará Boleslav. In: I. Boháčová (ed.): Stará Boleslav. Přemyslovský hrad v raném středověku. Mediaevalia archaeologica 5. Praha: Archeologický ústav AV ČR, Praha, 311-334.

Lutovský, M. 2001: Encyklopedie slovanské archeologie v Čechách, na Moravě a ve Slezsku. Praha: Libri.

Macháček, J. 2001: Zpráva o archeologickém výzkumu Břeclav-Líbivá 1995-1998. In: Z. Měřínský (ed.): Konference Pohansko 1999. 40 let od zahájení výzkumu slovanského hradiska Břeclav-Pohansko. Břeclav-Pohansko 3.-4. VI. 1999. Archaeologia mediaevalis Moravica et Silesiana I/2000. Brno: Masarykova univerzita, 39-62.

Měřínský, Z. 1984: Sídlištní objekty, jámy, kůlové jamky a žlábky prozkoumané při výzkumu velkomoravského pohřebiště u Velkých Bílovic (okr. Břeclav). Archaeologia historica 9, 39-63.

Miklíková, Z. 2006: Kostrové zvyšky koní zo staromad'arského pohrebiska v Leviciach. Slovenská archeológia LIV(2), 353-362.

Miklíková, Z., Ruttkay, M. 2003: Archeozoologická analýza depónií zvierat zo stredovekého sídliska v Bajči. In: V. Hašek, R. Nekuda, J. Unger. (eds.): Ve službách archeologie IV. Brno: Muzejní a vlastivědná společnost, 207-216.

Novotný, A. 1966: Osteologický materiál domácích zviřat ze sídlišt IX.-poč. XV. století. Rkp. diplomové práce. Univerzita Karlova. Př́rodovědecká fakulta. Katedra systematické zoologie. Uloženo: Knihovna Př́rodovědecké fakulty Univerzity Karlovy v Praze.

Peške, L. 1985: Domácí a lovná zvírata podle nálezů na slovanských lokalitách v Čechách. Sborník Národního muzea v Praze. Řada A Historie 39(3-4), 209-216.

Poulík, J. 1949: Staroslovanské pohřebiště u Dolních Věstonic na jižní Moravě. Archeologické rozhledy I, 130-131

Přichystalová, R. 2013: Intencionálne uloženie koňa - obeť či pohreb? Niekol'ko postrehov na základe nálezov z Břeclavi-Pohanska. Studia archaeologica Brunensia 18(2), 13-32.

Schmidt, E. 1972: Atlas of Animal Bones: For Prehistorians, Archaeologists and Quaternary Geologists. Amsterdam: Elsevier Publishing Company.

Staššíková-Štukovská, D. 2001: Vybrané nálezy z pohrebiska v Borovciach z pohl’adu začiatkov kostrového pochovávania staromoravských a nitranských Slovanov. In: L. Galuška, P. Kouřil, Z. Měřínský (eds.): Velká Morava mezi východem a západem. Sborník příspěvků z mezinárodní vědecké konference. Uherské Hradiště, Staré Město 28. 9. - 1. 10. 1999. Spisy Archeologického ústavu AV ČR Brno 17. Brno: Archeologický ústav Akademie věd České republiky, 371-388.

Tajer, A. 2001: Krčmaň (okr. Olomouc). Přehled výzkumů 42, 214.

Vignatiová, J. 1992: Břeclav-Pohansko II. Slovanské osídlení jižního předhradí. Brno: Masarykova univerzita.

Vitt, V. O. 1952: Lošadi Pazyrykskich kurganov. Sovetskaja archeologija $16,163-205$.

Wagner, K. 1930: Rezente Hunderassen. Eine osteologische Untersuchung. Skrifter utgitt av Det Norske VidenskapsAkademi i Oslo, Matematisk-naturvidenskapelig Klasse 9. Oslo: J. Dybwad.

Zábojník, J. 2004: Slovensko a avarský kaganát. Studia archaeologica et mediaevalia 6. Bratislava: Filozofická fakulta Univerzity Komenského.

Zapletalová, D. 2001: Slovanské osídlení na území města Brna do 10. století. Rkp. magisterské práce. Masarykova univerzita. Filozofická fakulta. Ústav archeologie a muzeologie. Uloženo: Knihovna Ústavu archeologie a muzeologie. 


\section{Summary}

The complex study of the Slavic settlement in Brno-Medlánky (investigated in 1987 and 2007; Benech 2019; Geisler 1987; 2008; Zapletalová 2001) required the evaluation of archaeozoological material. In essence, this consisted of two distinct components. The first, which was typical of every settlement, was the finding of evidence of animal food consumption - animal bone and teeth fragments. In this respect, the findings from Medlánky show a high prevalence of domestic cattle. There is a significantly lower number of domestic pigs and small ruminants (Tab. 1). This result might be influenced by a longer existence of the site as its features were not precisely dated. The group of domestic animals is complemented by horse, dog and chicken. Hunting animals are represented by the isolated skeletal remains of deer, roe deer, wild boar and aurochs.

However, what makes the site unique is the second group of archaeozoological finds. These are the deposited animal skeletons in features 558, 578 and 541 (Fig. 6, 8, 10). Specifically, these are two skeletons of dogs, a canine beast (probably a wolf), a horse and a domestic pig (Fig. 2, 4, 7, 9, 11). The latter was well preserved, except that its bones were not placed anatomically.

Although not unique, the occurrence of horse and dog skeletons in the early medieval period was infrequent. The skeletons of these species from Medlánky correspond to adult animals (except the beast from feature 578). The horse skeleton from feature 541 shows pathological changes in the thoracic spine area. These adhesions are due to the intensive use of the animal as a riding horse (withers height of $150 \mathrm{~cm}$ ), which died at an age of 12-13. I did not observe any traces on the skeleton that showed the cause of death. The animal was buried in a storage pit shortly after its demise.

The finding of the horse in Medlánky differs in comparison to the publications of horse burials from the early medieval period (Tab. 3, Fig. 13). Such finds are usually located in a burial ground or settlements associated with nearby human burials. However, the grave of the horse in Medlánky was found in neither of these. The marks on the spine confirm its intensive equestrian use and the fact that the horse was buried, not consumed, also testifies to its importance.

The skeletons of two dogs were located in feature 558. The individuals were similar in both size and age. In the case of the skeleton of dog I, there were also intense traces of cutting on the pelvis. This obvious evidence of post-mortem manipulation of the animal's body altered the skeletal deposition, which was not recorded in the documentation (Fig. 3).

The deposited skeletons of dogs from the early medieval period are quite rare with most found in the Břeclav-Pohansko fortified settlement and its close surroundings. The common feature of all these finds is their location in the settlement area, both on the floor of residential buildings and in waste pits. In this respect, the findings of dog skeletons from Medlánky can be considered to be customary.

\section{Kontakt}

\section{Gabriela Dreslerová}

Slovanské Hradiště v Mikulčicích, NKP

Valy 738

CZ-696 19 Mikulčice

g.dreslerova@masaryk.info 